\title{
Frihedsretorik og totalitære tendenser Sand oplysning og danskhed hos Grundtvig
}

\author{
Af Eberhard Harbsmeier
}

Inga Meincke: Vox Viva. Die »wahre Aufklärung« des Dänen Nikolaj Frederik Severin Grundtvig, Skandinavische Arbeiten Band 17, Universitätsverlag C. Winther, Heidelberg 2000, 371 sider.

I

Der findes, så vidt jeg kan overskue det, kun få virkelig kritiske opgør med Grundtvig i Grundtvigforskningen og litteraturen om Grundtvig. Især den udenlandske litteratur om Grundtvig er præget af mere eller mindre ukritisk beundring for ham. De problematiske og for nutidens læser uacceptable sider af Grundtvigs tænkning bliver enten omfortolket eller fortrængt. Sådan opstår et Grundtvigbillede, en slags eksportudgave, som ser ham i et meget positivt lys, som grundlægger af det moderne Danmark, der på en enestående måde formåede at forbinde kristen tradition med det modernes frihedssyn og indirekte er medansvarlig for den danske velfærdsmodel. Det skyldes ifølge dette billede Grundtvig, at begreber som folk og folkelighed i Danmark har en positiv klang og ikke har ført til en aggressiv nationalisme som i andre lande, specielt i Tyskland.

Inga Meinckes dissertation sætter et radikalt spørgsmålstegn ved dette billede. Bag Grundtvigs frihedsretorik ser hun »nationalistiske" (selvom hun undgår ordet) og autoritære tendenser: Den grundtvigske bevægelse var i starten ikke en folkelig bevægelse, men en esoterisk sekt med en autoritær leder, som var genstand for en næsten mytisk personkult. Han var en autoritær modstander af oplysningen (»Gegenaufklärer«), som ikke tålte modsigelse, som visionært talte »i livets navn« i stedet for at argumentere og indbyde til samtale. Han unddrager sig, det er Inga Meinckes kritik især imod Grundtvigreceptionen, det kritiske opgør. Den, der er kritisk, viser ifølge denne teori kun manglende »indlevelse« i Grundtvigs verden:

For kritisk opgør er der ikke plads. Når videnskaben fordømmes, betyder det, at man afstår fra forståelse, intersubjektiv relevans og kritik, som altid udsættes for beskyldningen om ignorant reception (s. 28).

Grundtvig som en repræsentant for reaktionær, antirationalistisk antioplysning - dette Grundtvigbillede - som i øvrigt også findes hos Grundtvigs samtidige fra udlandet er en tilstrækkelig forklaring på, hvorfor Grundtvig internationalt ikke har fundet nær så megen opmærksomhed som f.eks. H.C. Andersen og Søren Kierkegaard. Og Grundtvigs "progressive« virkningshistorie i Danmark bliver stort set afsløret som en misforståelse. 
Inga Meinckes bog er dog ingenlunde bare ren polemik, men en overordentlig materialerig, grundig og informativ dissertation. Efter en udførlig indledning, der præsenterer virkningshistorien i ind- og udland, analyseres Grundtvigs begreb om oplysning i tre skridt, der er disponeret biografisk. Her kommer Grundtvigs syn på historie, hans opgør med rationalismen, han koncept om folkelighed og danskhed, hans lære om det »levende ord « og hans konception af den folkelige højskole til orde. Det er primært en litteraturvidenskabelig afhandling, hvor især de litterære værker står i centrum fremfor teologiske og pædagogiske skrifter. Selvom man ikke deler forfatterens kritiske synspunkt, er bogen en imponerende præstation - kritisk, men ikke perfid, skrevet $i$ en saglig stil, overordentlig informativ, næsten med en overflod af materiale. Inga Meincke modstår trods al kritik den fristelse, på en plat måde bare at sætte Grundtvig i forbindelse med en »Blut und Boden« ideologi eller at ville afsløre ham som en præfascist.

Hvad der i Grundtvigs tænkning især byder Inga Meincke imod er - så vidt jeg kan se - to ting: Grundtvigs visionære teori om ægte oplysning og det levende ord er for det første dybt autoritær og totalitær og for det andet uløseligt knyttet sammen med en metafysisk idé om det danske sprogs og den danske kulturs overlegenhed, altså den grundtvigske »nationalisme«.

Jeg tager først det andet punkt op, Grundtvigs metafysiske opfattelse af danskheden. Men jeg vil indlede diskussionen om den grundtvigske »nationalisme« men en egen tysk erfaring: I min skoletid på et tysk gymnasium i efterkrigstiden havde vi en historielærer, der, for at sige det mildt, var ret »tysk-national« indstillet. Jeg var opdraget liberal-venstreorienteret og derfor i permanent opposition til denne tysk-nationale undervisning. Et yndlingsstridsobjekt var den tyske nationalsang, »Deutschlandlied", for mig ganske uacceptabelt. Jeg var af den opfattelse, at den skulle have været afskaffet, og det forekom mig at være et dårligt kompromis, som man ikke kunne være bekendt overfor nabofolkene, at bibeholde sangen - men kun at synge tredje vers.

Min historielærer havde en helt anden opfattelse: Man måtte, sådan som i den gængse fortolkning, ikke misforstå den tyske nationalsang i nationalistisk retning, sådan som det var sket i nazitiden. Sangen påstår ikke tyskhedens overlegenhed over andre folk i nationalistisk forstand, men taler om den legitime koerlighed til mit fædreland, som udmærket kan forenes med respekten for andre folk. Egentlig burde det hedde: Tyskland - elsker jeg over alt! På denne måde er teksten acceptabel som udtryk for ægte kærlighed til fædrelandet.

Jeg troede ikke på denne fortolkning, jeg tror stadig ikke på den slags forsøg på at gøre nationalismen til noget harmløst.

Danskere har gudskelov ikke en Deutschlandlied - men de har Grundtvig og den grundtvigske arv. Den grundtvigske »nationalisme« har - følger man Inga Meinckes dissertation - i sin virkningshistorie en lignende tendens som det fremstillede forsøg på at gøre Deutschlandlied harmløs: Man synger kun tredje vers, dvs. man tolker Grundtvigs tale om folkelighed og danskhed universalistisk almenmenneskeligt, man 
bagatelliserer de "nationalistiske« træk hos Grundtvig, som man jo ikke bare kan benægte, og tyder dem som en rar og ikke aggressiv patriotisme, der angiveligt ikke kan sammenlignes med andre folks nationalisme. Grundtvig har, sådan tolkes det, så at sige lutret nationalismen og gjort den acceptabel. De problematiske passager $\mathrm{i}$ Grundtvigs værker bliver overset, fortrængt, eller, hvor det ikke kan lade sig gøre, bagatelliseret. I denne proces kan der ifølge Meincke også i dag i Grundtvigreceptionen vise sig en sublim form en etnisk teori om den danske kulturs overlegenhed, en teori, hvorefter (måske bortset fra Holland) Danmark er det eneste land, hvor demokrati er noget naturligt, borgerrettigheder respekteres, social tryghed tilstræbes og krig som politisk middel afvises (S. 55, note 205 med en henvisning til en artikel af Finn Slumstrup). En tese, som ifølge Meincke ikke kan opretholdes »uden metafysiske eller bare racistiske« argumenter. En slags sublim skandinavisk form for farisæisk neonationalisme, der anser de nordiske lande for verdens mest tolerante og fredselskende - og samtidig fordækt dyrker perfide fordomme ikke kun imod Tyskland, men især også imod romanske, angelsaksiske og slaviske lande. Inga Meincke noterer f.eks., at bladet Information »bevidst" udbredte den "fejlinformation«, at den tyske forbundsdag efter murens fald skulle have sunget første vers af nationalsangen, hvor man ellers kun sang tredje vers, en fejlinformation som stadig udbredes af lederen af Sønderborg Slotsmuseum i en brochure (s. 58). Det fortrængte - sådan teorien vender tilbage: Den fortrængte grundtvigske nationalisme vender tilbage som en mere sublim, men ikke desto mindre farisæisk opfattelse af den nordiske kulturs og det nordiske demokratis overlegenhed.

Man må give forfatterinden ret deri: Grundtvigs "nationalistiske» ytringer kan ikke bagatelliseres som marginale udskejelser. Når Grundtvig taler om folk, mener han det danske folk, når han taler om modersmålet, taler han om det danske sprog. Grundtvigs berømte digt om sit modersmål er ikke et »lingvistisk, men et metafysisk koncept« (s. 277). Det drejer sig ikke om traditionel patriotisk fremhævelse af modersmålet, men om en totalitær metafysik om det danske sprogs overlegenhed. Grundtvig var dybt overbevist om, at det danske hjertesprog er andre sprog overlegent, som Inga Meincke dokumenterer med mange citater, herunder den smukke - omend sikkert forkerte - tese af Grundtvig, at walt Smukt og Godt lader sig oversætte paa Dansk, uden at tabe det Mindste, medens det bedste Danske ei lader sig oversætte paa noget Sprog, end ikke paa Engelsk, uden i det Mindste at tabe det Halve« (S. 43, 279, Det danske Fiirkløver, VU IV, s. 166). Inga Meincke kan også henvise til andre, mindre sympatiske sider hos Grundtvig, f.eks. at hans folkelighedskoncept gik ud på »etnisk renhed" og at Grundtvig totalt manglede sans for »multikulturel ligeværdighed«. Alt, hvad der er fremmed, bliver bekæmpet som udansk, og jøden Goldschmidt kan Grundtvig kun anerkende som gæst, ikke som del af det danske folkelige fællesskab. Inga Meincke karakteriserer Grundtvigs argumentation imod Goldschmidt som direkte "perfid" (s. 250f.). Nutidens fremmedhad kan påberåbe sig Grundtvig, og allerede 1864 talte den tyske digter Fontane om »den gamle professor Grundtvigs blasfemiske dogme«, at "Gud på den yderste dag vil kalde til dom på det danske sprog« (citat s. 15). Og som bogens andet motto oversætter Inga Meincke Grundtvigs valgopråb med allusioner til den tyske nationalsang: »Dänemark ... über alles« (citat s. 15). 
Det andet kritikpunkt i Inga Meinckes Grundtviginterpretation er Grundtvigs begreb om oplysning, der vil bekæmpe en plat rationalisme og sætte det levende ord imod en falsk fornufttro. Men bag frihedsretorikken viser sig autoritære tendenser, talen om den levende vekselvirkning tilslører kun denne totalitære tendens. Grundtvigs syn er visionær antioplysning, som ikke tåler modsigelse:

Grundtvigs teori om det levende ord er således imod den gængse opfattelse ikke et forsøg (blandt talrige sammenlignelige i det 19. århundrede) til at emancipere lægfolk - åndelige som verdslige. Den forskyder tydningsmagten fra fagfolk, der er underkastet ydre kriterier om videnskabelighed og dermed skiftende konkurrence, fagfolk, som principielt enhver kan regnes til, til den til verdens dechiffrør kaldede Ene, der foregiver at være den givne sandheds blotte medium. Gennem Grundtvig taler sagen, som han taler for, kirken, historien, kæmpeånden, Danmark og Gud ... Grundtvigs tale er forkyndelse, prædikestolen hans 'profetiske platform' og 'teologiske værksted', et åndeligt eksperimentarium, hvor - uden modsigelsens risiko - enhver 'opdagelse' for dens verdsliggørelse kan efterprøves med henblik på dens virkning. (s. 312)

Grundtvig tænker, ifølge denne tese reaktionært og autoritært. Dansker er, hvem Grundtvig bestemmer til det. Grundtvigs tvetydige holdning til den franske revolution er ikke

som man har ment, en tiltagende mere optimistisk livsholdning hos Grundtvig, men det kritiske punkt i hans hermeneutik: kravet på det eneste legitime blik på verden, påstanden om absolut immanens, der principielt må afvise kritisk tænkning (s. 187).

V

Inga Meincke vender sig imod Grundtvigs virkningshistorie, der »psykologiserer, æstetiserer, karikerer, ignorerer eller også afsvækkende accepterer« de totalitære træk i Grundtvigs tænkning og dermed bagatelliserer dem (s. 73). I modsætning til denne harmløse tolkning vil bogen tage Grundtvigs verdensbillede alvorligt og afdække de totalitære tendenser. Man må ikke gøre Grundtvig harmløs, man må tage ham ved det levende - ord.

At der findes disse betænkelige "nationalistiske» og totalitære tendenser hos Grundtvig, lader sig næppe bestride - heller ikke at der har været en tendens til at fortrænge eller bagatellisere disse aspekter. Spørgsmålet er derfor ikke så meget, om disse træk findes, men hvordan man omgås dem og hvordan de skal indordnes. At de drages frem, er bogens fortjeneste.

Alligevel er hendes tese ikke helt tilfredsstillende, der kort og godt afviser hele virkningshistorien som »gængs mening" og misforståelse. Man skal, det er min indvending, hermeneutisk tage den tidsbetingede forskel i betragtning og ikke måle Grundtvig (og andre) bare ud fra nutidens målestok. Bogen viser aspekter af 
Grundtvigs tænkning, der er fremmede for os i dag. Det er vigtigt. Man må også give hende ret $\mathrm{i}$, at man ikke bare i apologetisk interesse må bortinterpretere disse sider. Men derfor er det dog ikke illegitimt at tage opgaven op, at aktualisere og dermed $n y$ eller ominterpretere Grundtvig. Kan være, at Grundtvigs tale om modersmålet og folk hos ham selv meget mere snævert var ment som en metafysik om det danske sprogs og den danske kulturs overlegenhed - men virkningshistorien - og netop også den internationale højskolebevægelse - viser, at det kan være legitimt at tolke Grundtvig i universel og almenmenneskelig forstand. Kan være, at Grundtvig i sit digt Menneske først i virkeligheden mente Dansker først, men det må være tilladt at tolke netop dette digt universelt. Og at den smukke pinsesalme Var I ikke Galilaeer især taler om, at Ånden særligt lever i det danske modersmål (v. 3, se s. 74, note 311), var måske Grundtvigs intention, men det gør ikke en universel tolkning af salmen umulig. Skal ikke enhver aktualiserende interpretation, om det nu er Luther, Kierkegaard eller Grundtvig, skelne mellem det, der er tidsbestemt hos en forfatter og fremmed for os, og det, der kan aktualiseres? Og selv i en mere immanent Grundtviginterpretation skal der tages hensyn til, hvilken kontekstuel vaegt de af bogen påviste problematiske aspekter har hos Grundtvig. Man må ikke bortfortolke de "totalitære« træk hos Grundtvig, men man bør heller ikke overfortolke dem, som om Grundtvig kun har tænkt på den danske kulturs og det danske sprogs overlegenhed, når han talte om folk og modersmål. Man risikerer ellers at tabe de progressive sider af den grundtvigske arv af syne. Så entydig er sagen formentlig ikke: Også den "venstreorienterede« og progressive Grundtvigreception kan påberåbe sig tekster hos Grundtvig.

Uanset, hvordan det forholder sig: Til trods for bogens tese om autoritære og totalitære træk hos Grundtvig er jeg af den opfattelse, at Grundtvig i dag ikke kun kan tåle kritik og modsigelse, men ligefrem også har brug for det. Grundtvig er formentlig mere tjent med kritisk opmærksomhed end med plat apologetik. Derfor: En vigtig og værdifuld bog!

\section{Freiheitliche Rhetorik und totalitäre Tendenzen Wahre Aufklärung und Dänentum bei Grundtvig}

\section{Von Eberhard Harbsmeier}

Inga Meincke: Vox Viva. Die »wahre Aufklärung« des Dänen Nikolaj Frederik Severin Grundtvig, Skandinavische Arbeiten Band 17, Universitätsverlag C. Winther, Heidelberg 2000, 371 Seiten.

Es gibt, soweit ich orientiert bin, nur wenige wirklich kritische Auseinandersetzungen mit Grundtvig in der Grundtvigliteratur und Grundtvigforschung. Vor allem die ausländische Literatur über Grundtvig ist geprägt von mehr oder weniger unkritischer Bewunderung für Grundtvig, die problematischen und für den heutigen Leser inak- 